\title{
ALPINE BASEMENT OUTCROPS AT NORTHERN PELOPONNESUS: IMPLICATIONS FOR THE EARLY STAGES IN THE EVOLUTION OF THE CORINTH RIFT
}

\author{
Skourtsos E. ${ }^{1}$, Kranis H. ${ }^{1}$, Zambetakis-Lekkas A. ${ }^{1}$, Gawthorpe R. ${ }^{2}$ and \\ Leeder M. ${ }^{3}$ \\ ${ }^{1}$ National and Kapodistrian University of Athens, Faculty of Geology and Geoenvironment, 15784 \\ Zographou, Athens Greece, eskourt@geol.uoa.gr,hkranis@geol.uoa.gr,zambetaki@geol.uoa.gr \\ ${ }^{2}$ University of Bergen, Department of Earth Science, Bergen, Norway, rob.gawthorpe@geo.uib.no \\ ${ }^{3}$ University of East Anglia, School of Environmental Sciences, Norwich, UK, M.Leeder@uea.ac.uk
}

\begin{abstract}
We focus on the central and eastern southern onshore parts of the Corinth Rift (CR), where basement outcrops are few and of limited extent, to study three key locations: a basement inlier east of Xylokastro, a new outcrop of the Tripolis Unit at the western edge of the Xylokastro horst, and a re-mapped and re-evaluated outcrop of the Pindos Unit northwest of Nemea. The results of this study show that there are elements which could help overcome the significant difficulties in our understanding of the structure and evolution of the rift, posed by the lack of basement outcrops in the central and eastern onshore parts of the Rift. This, in turn, calls for a reconsideration of the generally accepted idea that the broader onshore eastern sector of the CR lacks significant basement and intrabasinal faults.
\end{abstract}

Keywords: Post-orogenic extension, Tripolis Unit; Pindos Unit.

\section{Пєрі́́ $\eta \psi \eta$}

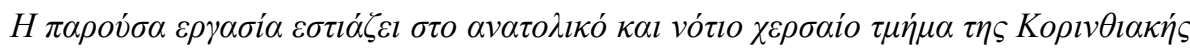

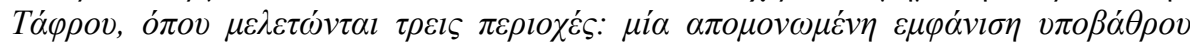

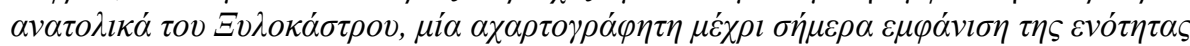

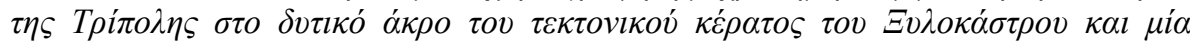

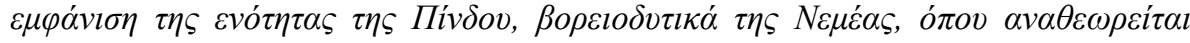

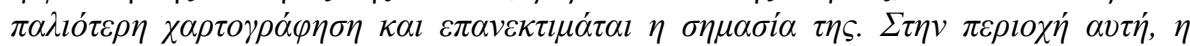

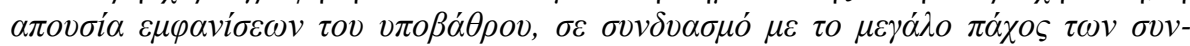

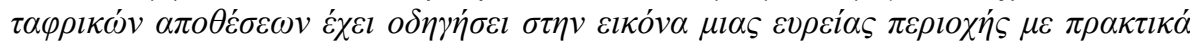

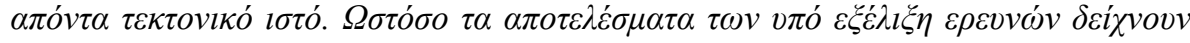

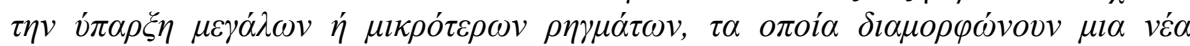

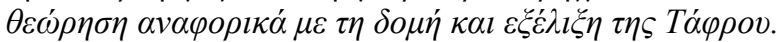

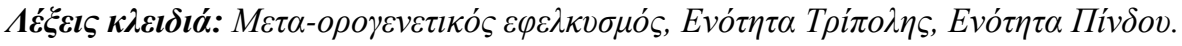

\section{Introduction}

The Gulf of Corinth Rift (CR), one of the most rapidly extending continental rifting zones worldwide, is a young structure, overprinting at high angles the tectonic grain of the Hellenides, inherited from the alpine orogeny. At its present form it is ca $100 \mathrm{~km}$ long and it comprises an active, mainly offshore 
part 30-40 km wide, which corresponds to the Gulf of Corinth and a less active, onshore landstrip (ca $40 \mathrm{~km}$ wide) along the Northern Peloponnesus (Fig. 1). Current extension rates across the rift are in the order of 10-16 mm/yr (e.g. Avallone et al., 2004), with extension oriented approximately N-S (e.g. Clarke et al., 1998). The origin of extension, in general and particularly the strain focusing on the CR is still matters of debate; suggested models involve subduction-driven rollback and back-arc extension, gravitational collapse of thickened crust, or influence from the westward propagation of the North Anatolian Fault (e.g. Armijo et al., 1996; Jolivet et al., 2010).

The understanding of the Corinth rift evolution calls, among others, for constraints on the pre-rift (alpine) structure and geometry. The quantification of parameters such as the displacement of riftbounding faults (but also of intrabasinal ones) is facilitated if a known marker can be located both on their hanging- and footwalls. The tectonic contacts between the geotectonic units that build the tectonic edifice of the pre-rift basement have been used as markers for the estimation of the extension across the $\mathrm{CR}$, the displacement of the onshore rift-forming faults and the palinspastic reconstruction of the rift (e.g. Ford et al., 2013). One such marker, which was used in other parts of the CR, is the tectonic contact of the Pindos Unit pelagic limestones over the flysch of the Tripolis Unit (e.g. Sorel, 2000; Skourtsos and Kranis, 2009). However, this is mainly true for the western southern onshore part of the rift, because its southern eastern onshore segment (i.e. between Xylokastro in the west and Corinth in the east), the absence of basement outcrops has led to the assumption that this part of the rift is devoid of large faults and follows a different evolutionary pattern.

In the light of the above, we focus on the central and eastern southern onshore parts of the CR, where basement outcrops are few and of limited extent. We study three locations: a basement inlier east of Xylokastro, which has been mapped and appears in the published IGME map (Koutsouveli et al., 1989), a newly mapped outcrop of the Tripolis Unit, at the western edge of the Xylokastro horst, and a re-mapped and re-evaluated outcrop of the Pindos Unit North-west of Nemea. These may aid our understanding of the structural grain in a relatively poorly investigated area within a continental rift of world-wide importance.

\section{Geological and Tectonic Setting}

The southern onshore part of the CR extends from Mt Panakhaikon in the west to Corinth in the east (Skourtsos and Kranis, 2009). Terrestrial and marine sediments, with thickness exceeding $2.8 \mathrm{~km}$, were deposited during the phases of the CR evolution. These synrift deposits were classified in three groups, namely (i) a lower group, of probable Pliocene age, which comprises terrestrial deposits, including alluvial fans in the west and lacustrine sediments in the east; (ii) a middle group, which includes large marginal fan deltas; and an upper group, which comprises the marine and fluvial terraces that flank the southern onshore part of the CR at Northern Peloponnesus (Rohais et al., 2007). This broad zone has been undergoing uplift, albeit at varying rates along the rift axis, and synrift sediments are now found at altitudes above $1.6 \mathrm{~km}$ (Dufaure, 1977).

The pre-rift Hellenide ('alpine') basement of the CR comprises various Tethyan fragments, which were successively detached from the subducting African plate and accreted to the southern margin of the Aegean microplate on the Hellenic subduction zone.

As regards the central part of the Northern Peloponnesus, the tectonically lower Unit is the PhyllitesQuartzites (PQ) Unit, which consists of high-pressure mica schists and quartzites, along with rare ultramafic rocks. The Tripolis Unit (TU), which overlies the PQ is characterized by a thick shelf U. Triassic- U. Eocene carbonate sequence, deposited on an Upper Palaeozoic - L. Triassic volcanosedimentary complex, collectively known as the Tyros Beds. This carbonate sequence is capped by a flysch sequence, of L. Eocene - Oligocene age. The uppermost Unit of the pre-rift basement is the Pindos Unit (PU), a Mesozoic sequence of pelagic sediments (limestones and cherts), topped by a Palaeocene - Eocene flysch. At the eastern onshore part of the CR (Corinth and Perahora peninsula), the pre-rift basement is represented by the rocks of the Sub-Pelagonian Unit (SU) and comprise mainly Upper Triassic to Jurassic neretic limestones, followed by Mid-Upper Jurassic 
shales, sandstones and cherts. Finally, an ophiolite thrust sheet is found at Geraneia Mountains, in the eastern edge of the Gulf of Corinth.

The synrift sediments in the Northern Peloponnesus have been deposited upon the alpine, pre-rift basement and the western and central portions of the CR are characterized by E-W to ESE-WNW faults that acted during the early stages of rift evolution now juxtapose basement outcrops against synrift sediments (Skourtsos and Kranis, 2009; Ford et al., 2013).

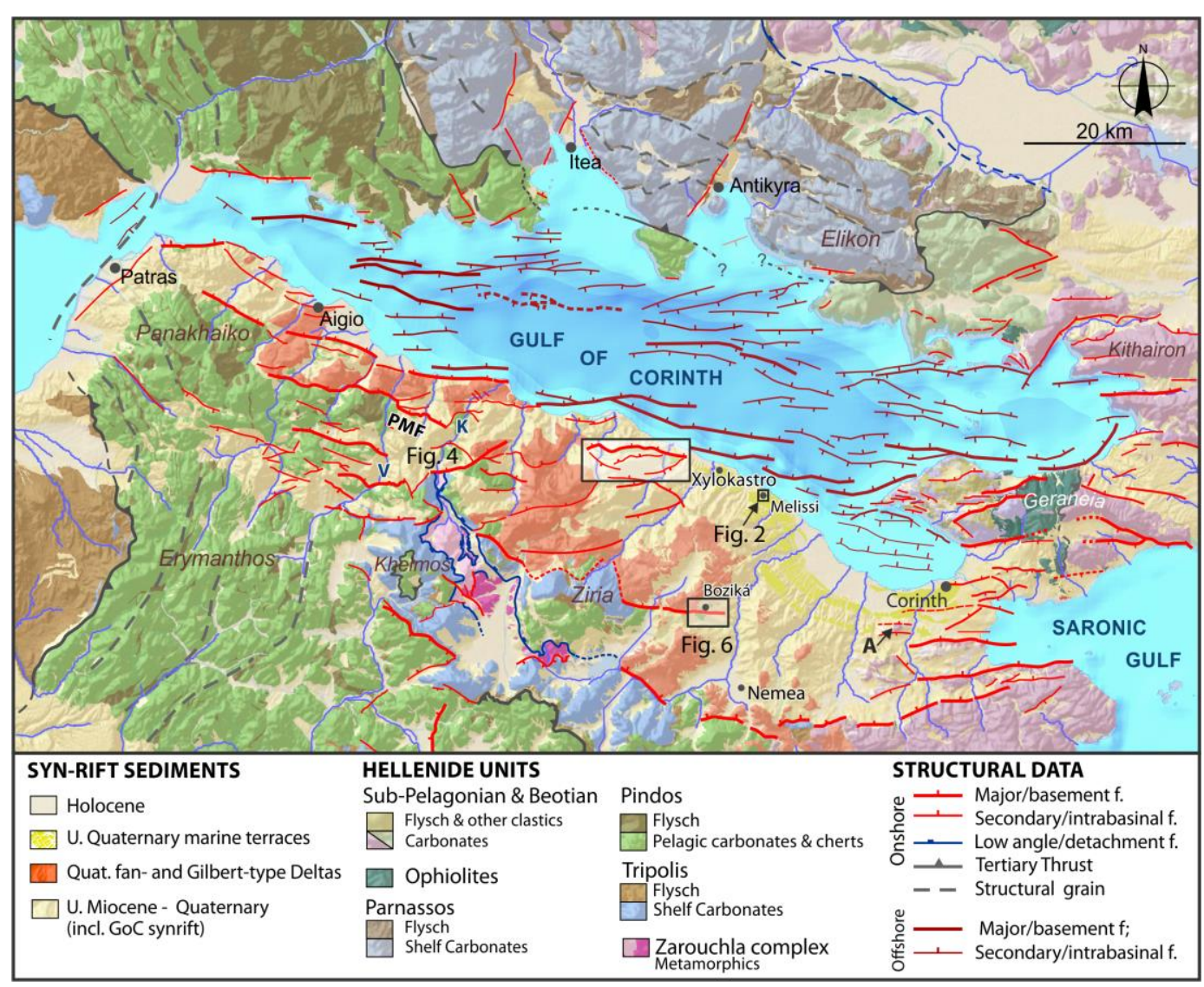

Figure 1 - Synthetic tectonic map of the Gulf of Corinth, to show the Hellenide Units that constitute the basement to the GoC Rift, modified after Kranis et al. (2015). Structural data from Beckers et al. (2015), Charalampakis et al. (2014), Nixon et al. (subm.) (offshore), Ford et al. (2009, 2013) (south -western onshore), Skourtsos and Kranis (2009) and Leeder et al. (2013) (southern central) Freyberg (1973), Collier and Dart (1991) (eastern onshore); and own mapping. Dashed line offshore delineates the possible eastern margin of the External Hellenides beneath the Gulf. A: Akrocorinth; V: Vouraikos; K: Krathis.

\section{The Melissi inlier}

A minor basement outcrop (area ca $0.02 \mathrm{~km}^{2}$ ) consisting of carbonates and clastics, is located at the seaside town of Melissi, $5 \mathrm{~km} \mathrm{SE}$ of Xylokastro. The carbonates occupy a small knoll, just north of the Corinth-Patras highway, while the clastics were mainly exposed on the roadcut, covered, capped by an U. Pleistocene marine terrace (Fig.2). The construction of the new highway, through widening of the original route exposed the clastic sequence for a distance of ca $300 \mathrm{~m}$ along the road, but subsequently involved the erection of retaining walls, which have now covered almost the entire outcrop of the clastics. 
The clastics consist of brown clays, intercalated with dm-thick banks of calcareous conglomerates and fine-grained sands and include rare angular to well-rounded limestone blocks $\left(<0.5 \mathrm{~m}^{3}\right)$. The sequence appears deformed in tight folds at the eastern part of the exposure, but towards the west it presents a steady NW-dipping geometry. Information provided by professional drillers in the area (F. Chatoupis, 2012, pers. comm.) confirms that the within a ca $5 \mathrm{~km}$ distance to the $\mathrm{SE}$ and $\mathrm{S}$ from the Mellissi outlier, the synrift deposits are underlain by clastic sediments with close affinities to the clastic sediments exposed along the roadcut.

The carbonates are whitish, massive or thick-bedded and densely fractured limestones, while small, irregular calcite veins run through the carbonate mass. The nature of the contact between the clastics and the carbonates could not be verified in the field, as it obscured by the national road. The northern, steep boundary of the calcareous mass is densely fractured by E-W steep planar discontinuities and corresponds to a degraded fault scarp.

A number of samples was obtained both from the clastic sequence, especially from the olistholites and the conglomeratic intercalations and from the calcareous mass. The microfacies analysis of the breccia and conglomerate banks, included in the clastic sequence revealed that their elements may be composed of fragments of one stratigraphic level or different stratigraphic levels of the Tripolis platform. The elements may be of small size (up to $1 \mathrm{~mm}$ ) or be coarser ones. More specifically, in a microbrecciated bank of Tertiary, age evidenced by the presence of Globorotalia sp. (Fig. 3), small sized elements of exclusively Late Cretaceous age are found in the cement, including fragments of bivalves, rudists, echinoids, as well as Orbitoides media, Lepidorbitoides sp., Siderolites calcitrapoides, Cuneolina sp, indicating L. Campanian-Maestrichtian age.

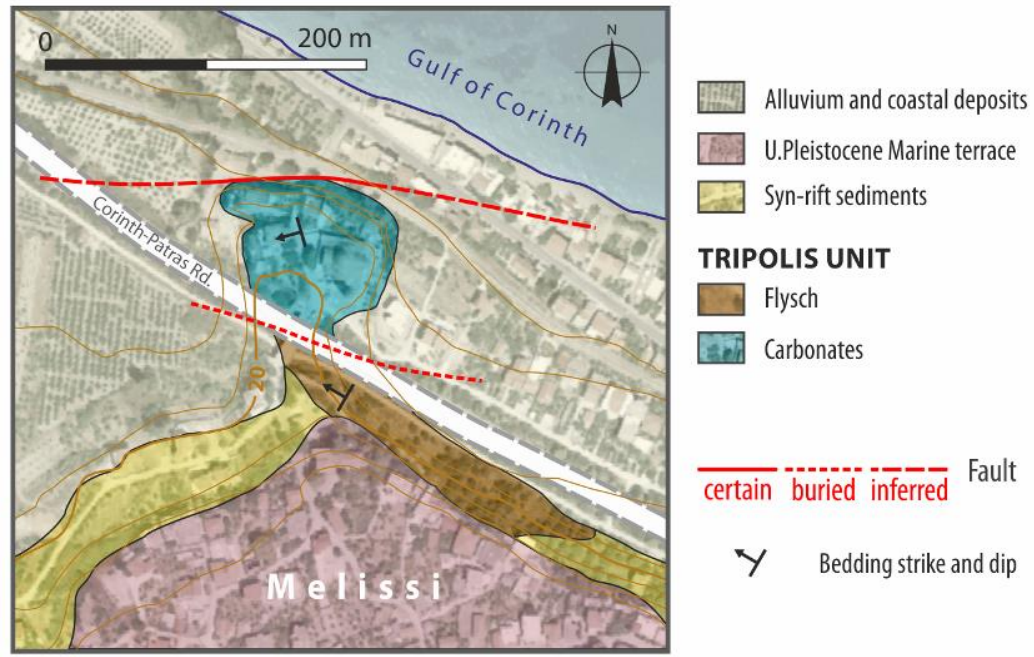

Figure 2 - Map of the Melissi inlier (see Fig 1. for location). The knoll north of the highway is an outcrop of $\mathrm{L}$. Paleocene - E. Eocene age limestones, in faulted contact with the flysch of the Tripolis Unit. The marine terrace that caps the hill south of the highway corresponds to the MIS3.3 (ca 55 ka BP) Kariotika -1 terrace (Armijo et al., 1996).

In other cases, finer and coarser unsorted elements are found. Different stratigraphic levels are recognized: Elements of mudstone containing Ophthalmidiids, ostracods, Bolivinopsis, Aeolisaccus kotori indicate a Late Cretaceous age, of inner platform provenance. Ped and fenestra structure consisting of ellipsoidal to round pelletoid elements, separated by irregular pore spaces, observed in certain breccia elements, indicate an intertidal to supratidal provenance. 

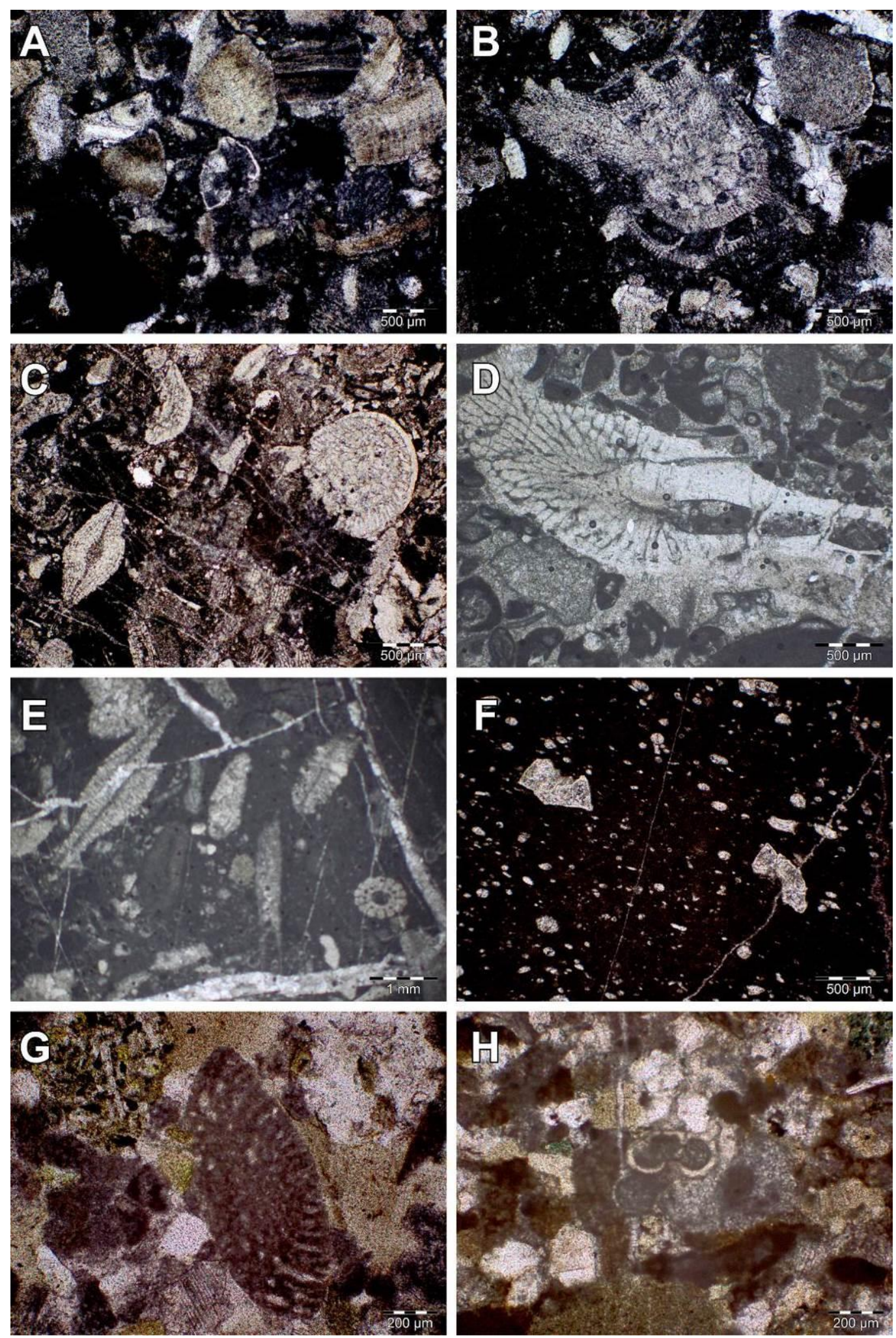
Figure 3 - Microphotographs from samples obtained from the study sites. Samples A-C and D-E are from the clastics and the carbonates of the Melissi inlier, respectively; F-H are from the Pindos outcrops at Boziká. (A): Globorotalia sp. in the matrix of a microbreccia containing fragments of bivalves and rudists; (B): Siderolites calcitrapoides; $(\mathrm{C})$ : bioclastic limestone with Chapmanina and Asterodiscus; (D): Biosparite with Ranikothalia; (E):

Biomicrite mudstone with Discocyclina and echinoid spine; (F): Biomicrite mudstone with Globotruncanidae; (G): Orbitolinid in clastic limestone; $(\mathbf{H})$ Hedbergella cf trochoidea

(Gandolfi).

Similar facies are observed in different levels of the upper Cretaceous sequence of Tripolitza platform (Zambetakis Lekkas et al., 1988, 1998, 2007; Pomoni-Papaioannou and ZambetakisLekkas, 2009), but also of Lower Cretaceous age (Zambetakis-Lekkas et al., 1995). These elements are found among others of sandstone and microfossils that are transported as independent breccia elements. Their different stratigraphic attribution and their occasional intensively eroded appearance testify their transportation.

On the other hand, the micropalaeontological study of the carbonates showed that they consist of biomicritic-biosparitic limestones, mudstones-wackestones or grainstones and are characterized by the abundance of corals. Hydrozoans, bivalves, echinoderms Algues Melobesia and rare gastropods are also present, along with foraminifera as miliolids, rotaliids, Discocyclina sp.and Ranikothalia, which yield a Late Paleocene - Early Eocene age (Fig. 3). The fact that the carbonates belong to the underlying stratigraphic level of the clastics (i.e. U. Eocene) points to the existence of a tectonic contact between these two formations, which is interpreted as a fault that has been obscured by the construction of the motorway.

\section{Occurrence of the Tripolis Unit in the Xylokastro horst block}

A major basement outcrop occurs south-west of Xylokastro. This is elongated fault block, uplifted in the footwall of the Xylokastro fault. Recently published work (Leeder et al., 2012) shows that this block corresponds to an intrabasinal horst, faulted against syn-rift sediments both on its northern margin (via the Xylokastro F.), but also on its eastern and southern margins, via the Koutsos fault. Until recently, the basement outcrops within the Xylokastro block were considered to comprise solely the formations of the Pindos Unit. However, geological mapping in the area showed that the underlying (lower) Tripolis Unit is also exposed in this horst block.

The Tripolis outcrop is located at the western edge of the horst and covers an area of ca $0.6 \mathrm{~km}^{2}$, at a moderately north-dipping slope. It consists solely of carbonate rocks and specifically thick-bedded to massive light or dark grey limestones, which are intensely brecciated and dolomitized. This is partly attributable to the fact that the slope that the carbonates occur practically coincides with the fault surface (i.e. a 'fault-slope') of the Xylokastro fault. Nonetheless, the facies and sedimentary structure of the carbonates have close affinities to the Late Cretaceous-Eocene limestones of the Unit.

The outcrop occurs as a lower-order horst within the Xylokastro block, meaning that it is in faulted contact with the Pindos limestones in the south and south-east and with the syn-rift sediments in the north and north-west. The southern margin of the outcrop is an E-W, south-dipping fault, which juxtaposes the Tripolis carbonates against the Pindos limestones. Its northern margin corresponds to the western termination of the main, north-dipping Xylokastro fault, which juxtaposes the Tripolis rocks against synrift sediments. The latter are deformed in a well-defined fault-drag fold, with northerly structural dips increasing towards the trace of the Xylokastro Fault. 


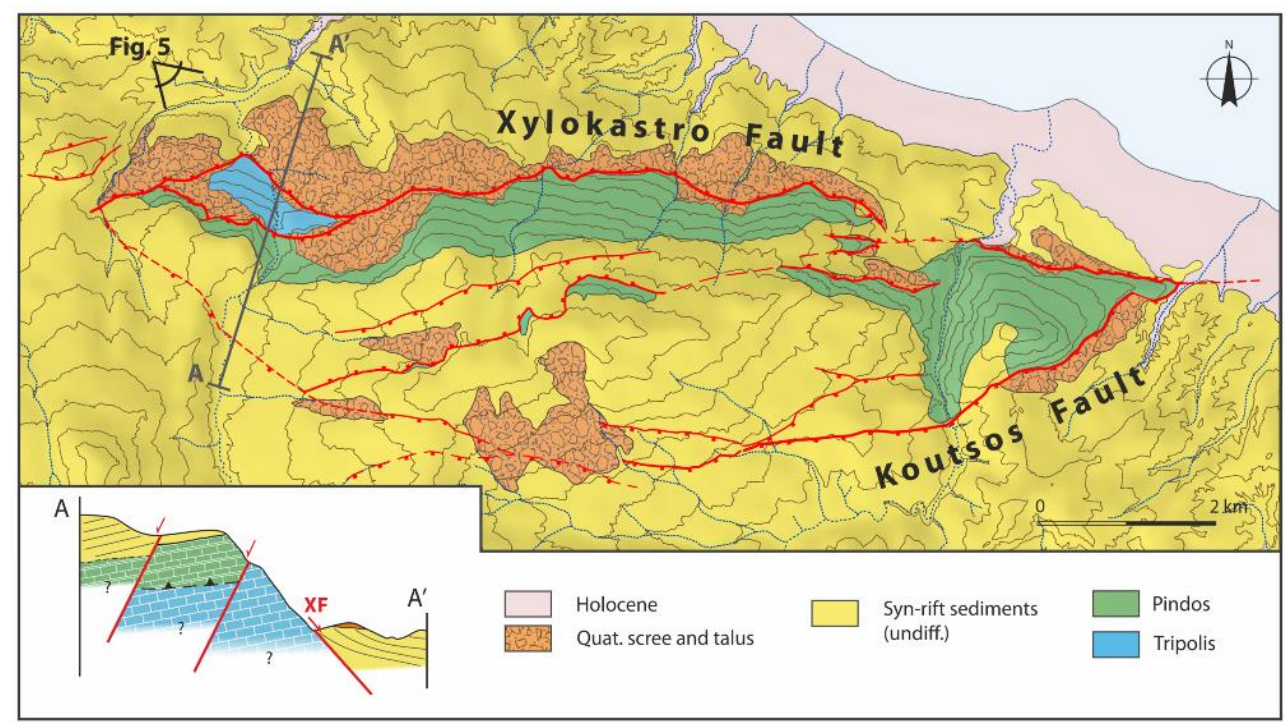

Figure 4 - Geological map of the Xylokastro horst. See Fig. 1 for location. The basement outcrops within the horst belong to the formations of the Pindos Unit (cherts and limestones), with the lower Tripolis Unit outcropping at the western part of the horst.
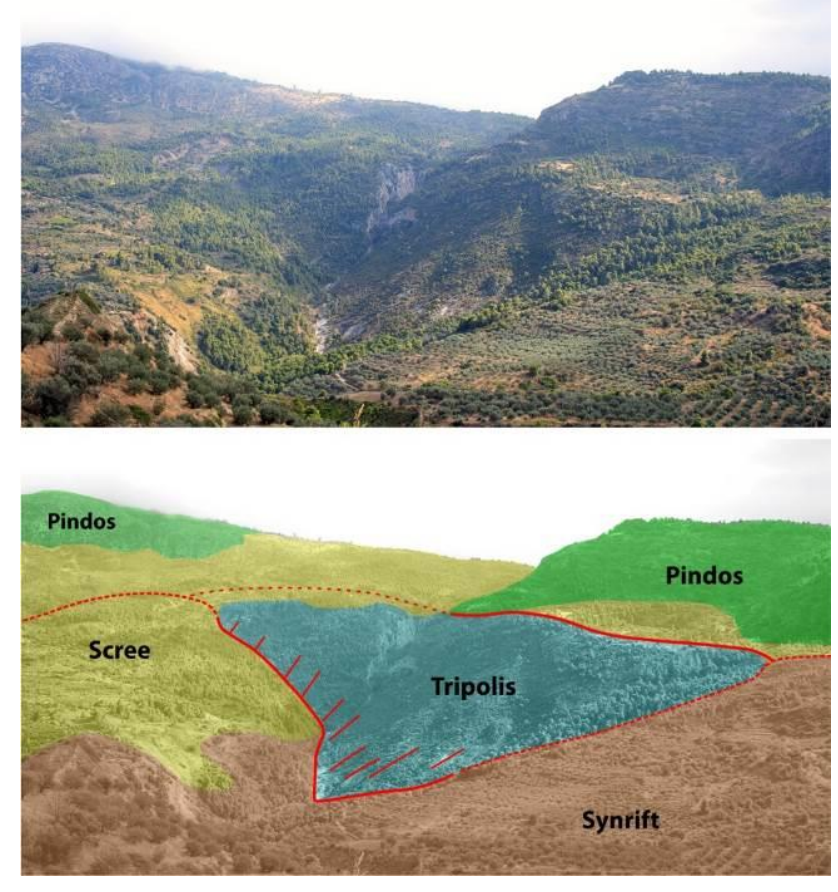

Figure 5 - The previously unmapped outcrop of Tripolis Unit limestones at the western tip of the Xylokastro horst. View to ESE.

\section{The Pindos inlier group at Boziká}

Geological mapping in the area of the Boziká settlement (Fig .6), showed a number of occurrences of the Pindos Unit, overlain by synrift deposits of the CR. The northernmost outcrop consists of green mudstones, clastic limestones with red and green clasts and muddy radiolarites that pass 
southwards to red mudstones and further the south to laminar, thin-bedded, and whitish to beige limestones with thin black chert nodules. The limestones (biomicrites, mudstones) contain Globotruncana asymetrica (Sigal) and Globotruncana concavata (Grotzen) are determined, indicating Santonian age (Fig. 3). The medial outcrop consists of green sandstones, mudstones and fine conglomerates containing quartzitic and volcanic clasts, and intercalations of clastic limestones that include Orbitolinidae and Miliolidae and Hedbergella cf trochoidea (Gandolfi). (Fig. 3). The latter narrows down the age of the formation to Aptian- E. Cenomanian. The southernmost outcrop has also comparable lithology, although green mudstones and sandstones dominate. The fossils, and the microfacies both in the clastics and in the carbonates show that these outcrops belong to the "first flysch" of the Pindos Unit as it was named by Aubouin (1959) and was included by Fleury (1980) in the Radiolarites Formation (upper member).

The clastics are folded in places with closed to tight folds striking $\mathrm{N} 30^{\circ}$, but also isoclinal folds and microbending, striking $\mathrm{N} 150^{\circ}$ and N-S, respectively, were observed.

The southernmost occurrence of the Pindos Unit is covered unconformably by sandstones, mudstones and conglomerates with dips up to $40^{\circ}$ to the S-SSW, which further south are covered by a thick sequence of conglomerates and sandstones that are part of a large alluvial fan delta. The alpine outcrops are faulted by a suite of E-W, N-dipping high-angle normal faults, which juxtaposed them against the synrift sandstones and mudstones which exhibit high-angle southerly dips. The latter are covered uncomfortably by a group of conglomerates and coarse sandstones of another alluvial fan delta.

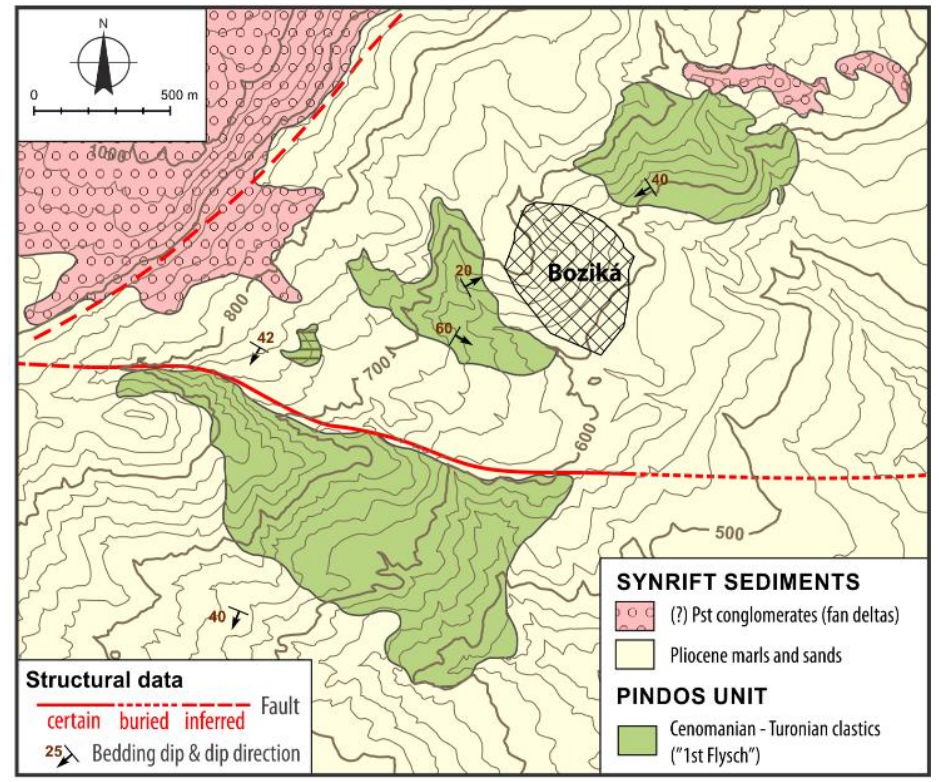

Figure 6 - Geological map of the area around Boziká (see Fig. 1 for location).

\section{Discussion - Implications}

The lack of basement outcrops in the central and eastern onshore parts of the Corinth Rift poses significant difficulties in our understanding of the structure and evolution of the rift. Detailed geological and structural mapping, in the last few years, however, has shown that there are elements which could help overcome some of these obstacles.

The Melissi inlier is one of these 'stepping stones' between the Xylokastro block in the west (which is the easternmost basement outcrop along the Gulf of Corinth shore) and the next significant basement exposure, which is at the Akrocorinth horst block in the east (Fig. 1). The importance of 
this outcrop is enhanced by the results of offshore geophysical surveys. Specifically, Taylor et al. (2011) show that a set of N-dipping offshore faults, located off the coast of Melissi (the Sythas and offshore Xylokastro faults) are responsible for the formation of a secondary footwall basin, while the continued activity of these faults has led to significant footwall uplift, eventually leading to the subaerial exposure of basement rocks, such as at the Melissi inlier.

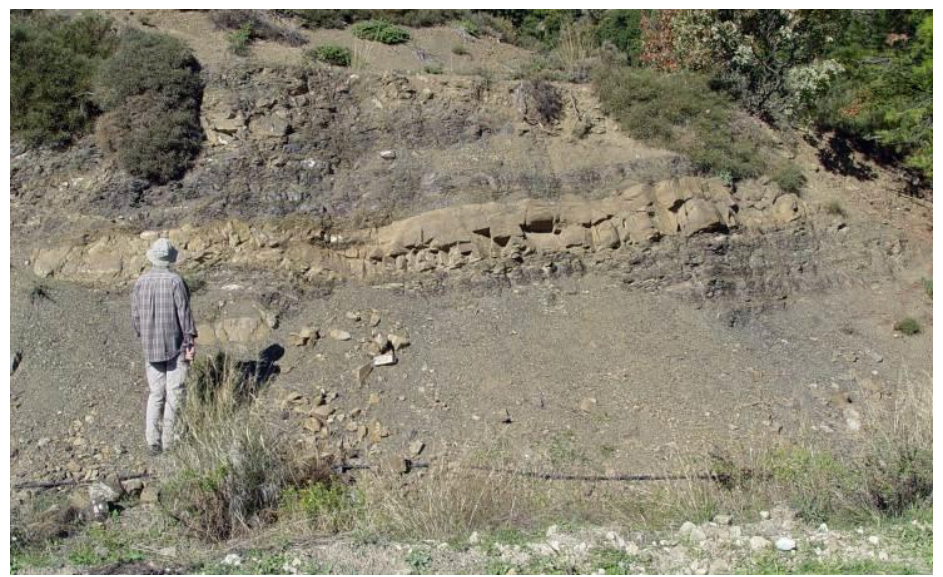

Figure 7 - Outcrop of the ' $1{ }^{\text {st }}$ Flysch' Pindos formation at Boziká.

The Tripolis outcrop at the Xylokastro horst and the Melissi inlier are the two northernmost exposures of the Unit at Northern Peloponnesus, within the onshore landstrip of the Corinth Rift. Other Tripolis outcrops are located at the footwalls of rift-related faults, such as the Valimi and Pyrgaki-Mamoussia Faults, in the valleys of Krathis and Vouraikos, respectively (Fig. 1). In these locations the contact between the Tripolis and Pindos Units is mappable and it corresponds to an extensional fault that has replaced the original thrust contact between these units. Such extensional structures could be related the early syn-orogenic extension that has affected the central and southern Peloponnesus in the U. Miocene (Skourtsos, 2002; Skourtsos and Lekkas, 2010), but they can also be linked to the formation and evolution of the Corinth Rift. In the latter case the magnitude of extension across the rift has to be greater than what was calculated through palinspastic reconstructions (e.g. Sorel, 2000), which do not take into account these south-dipping faults.

Geological mapping and micropalaeontological analysis of the Pindos Unit outcrops at Boziká show that they belong to the middle Cretaceous clastic series of the Unit, instead of the Palaeocene Eocene Pindos Flysch, as shown by Tataris et al. (1970). The presence of Hedbergella cf trochoidea (Gandolfi) within a stratigraphic horizon from the middle part of the formation shows that the onset of the deposition of the "First Flysch" in the area was earlier than the age indicated by the fossil itself, probably during the Barremian, as suggested by Fleury (1980) for central Greece.

The Pindos outcrops at Bozika can be described as rotated fault blocks, controlled by E-W, northdipping normal faulting, which is connected to a major marginal fault along the northeastern flanks of Mt Ziria. Additionally, the presence of two big alluvial fan deltas north and south of these faulted outcrops can be compared to the evolution of the central onshore CR where multiple and diachronous fan deltas were deposited along the southern margins of the rift, as fault activity migrated northwards.

Finally, the occurrence of the basement outcrops themselves and the fact that they are fault controlled, raises the issue of re-consideration of the structural grain in the onshore eastern sector of the Corinth Rift, where the image of an extended area devoid of significant basement and intrabasinal faults is based on dated data and maps, which should be revised. 


\section{Acknowledgments}

We thank an anonymous reviewer for constructive comments on the manuscript.

\section{References}

Armijo, R., Meyer, B., King, G., Rigo, A. and Papanastassiou, D., 1996. Quaternary evolution of the Corinth Rift and its implications for the Late Cenozoic evolution of the Aegean, Geophysical Journal International, 126, 11-53.

Aubouin, J., 1959. Contribution à l'étude géologique de la Grèce septentrionale, les confins de l'Epire et de la Thessalie, Ann. Geol. Pays Hell. 10, 526.

Avallone, A., Briole, P., Agatza-Balodimou, A.M., Billiris, H., Charade, O., Mitsakaki, C., Nercessian, A., Papazissi, K., Paradissis, D. and Veis, G. 2004. Analysis of eleven years of deformation measured by GPS in the Corinth Rift Laboratory area, Comptes Rendus Géosciences, 336, 301-311.

Beckers, A., Hubert-Ferrari, A., Beck, C., Bodeux, S., Tripsanas, E., Sakellariou, D. and De Batist, M., 2015. Active faulting at the western tip of the Gulf of Corinth, Greece, from highresolution seismic data, Marine Geology, 360, 55-69.

Bell, R.E., McNeill, L.C., Henstock, T.J. and Bull, J.M., 2011. Comparing extension on multiple time and depth scales in the Corinth Rift, Central Greece, Geophysical Journal International, $186,463-470$.

Charalampakis, M., Lykousis, V., Sakellariou, D., Papatheodorou, G. and Ferentinos, G., 2014. The tectono-sedimentary evolution of the Lechaion Gulf, the south eastern branch of the Corinth graben, Greece, Marine Geology, 351, 58-75, doi: 10.1016/j.margeo.2014.03.014.

Clarke, P.J., Davies, R.R., England, P.C., Parson, B., Billiris, H., Paradissis, D., Veis, G., Cross, P.A., Denys, P.H., Ashkenazi, V., Bingley, R., Kahle, H.-G., Muller, M.-V. and Briole, P., 1998. Crustal strain in central Greece from repeated GPS measurements in the interval 1989. 1997, Geophysical Journal International, 135, 195-214.

Dufaure, J.J. 1977. Néotectonique et morphogenèse dans une péninsule méditerranéenne: la Péloponnèse, Revue de Géographie Physique et de Géologie Dynamique, 19(1), 27-58.

Fleury, J., 1980. Les zones de Gavrovo-Tripolitza et du Pinde-Olonos (Grèce continentale et Péloponnèse du Nord). Evolution d'une plateforme et d'un bassin dans leur cadre alpin, Memoire de la Soc. Geol. Nord, $651 \mathrm{pp}$.

Flotte, N., Sorel, D., Muller, C. and Tensi, J., 2005. Along strike changes in the structural evolution over a brittle detachment fault: Example of the Pleistocene Corinth-Patras rift (Greece), Tectonophysics, 403, 77-94.

Ford, M., Rohais, S., Williams, E.A., Bourlange, S., Jousselin, D., Backert, N. and Malartre, F., 2013. Tectono-sedimentary evolution of the western Corinth rift (Central Greece), Bas. Res., 25, 3-25.

Ford, M., Williams, E.A., Malartre, F. and Popescu, S.-M., 2009. Stratigraphic Architecture, Sedimentology and Structure of the Vouraikos Gilbert-Type Fan Delta, Gulf of Corinth, Greece, In: Nichols, G., Williams, E.A. and Paola, C., eds., Sedimentary Processes, Environments and Basins: A Tribute to Peter Friend. Blackwell Publishing Ltd., Oxford, 49-90.

Jolivet, L. Labrousse, L., Agard, P., Lacombe, O., Bailly, V., Lecomte, E., Mouthereau, F. and Mehl, C. 2010. Rifting and shallow-dipping detachments, clues from the Corinth rift and the Aegean, Tectonophysics, 483, 287-304.

Koutsouveli, A. and Mettos, A., 1989. Geological Map of Greece, scale 1:50,000, Xylokastro Sheet, Athens, Greece.

Kranis, H., Skourtsos, E., Gawthorpe, R., Leeder, M. and Stamatakis, M., 2015. Pre-rift basement structure and syn-rift faulting at the eastern onshore Gulf of Corinth Rift, Geophysical Research Abstracts, 17, EGU2015-2575, EGU General Assembly 2015.

Nixon, C., and fourteen others. Rapid spatio-temporal variations in rift structure during development of the Corinth Rift, central Greece, Submitted to Tectonics. 
Pomoni-Papaioannou, F.A. and Zambetakis-Lekkas, A., 2009. Facies associations of the late Cenomanian carbonate platform of Tripolitza subzone (Vitina, Central Peloponnesus, Greece): evidence of long-term/terrestrial subaerial exposure, Boll. Soc. Geol. It., 128, 1.

Rohais, S., Eschard, R., Ford, M., Guillocheau, F. and Moretti, I., 2007. Stratigraphic architecture of the Plio-Pleistocene infill of the Corinth rift: Implications for its structural evolution, Tectonophysics, 440, 5-28.

Skourtsos, E., 2002. The tectonic setting of the eastern margin of the Mt Parnon tectonic window. Unpubl. PhD. Thesis, National and Kapodistrian University of Athens, Athens (in Greek with English extended abstract).

Skourtsos, E. and Kranis, H., 2009. Structure and evolution of the western Corinth Rift, through new field data from the Northern Peloponnesus, Geological Society, London, Special Publications, 321, 119-138.

Skourtsos, E. and Lekkas, S., 2010. Extensional tectonics in Mt Parnon (Peloponnesus, Greece), Int. J. Earth Sci. (Geol. Rundsch.), doi 10.1007/s00531-010-0588-0.

Taylor, B., Weiss, J.R., Goodliffe, A.M., Sachpazi, M., Laigle, M. and Hirn, A., 2011. The structures, stratigraphy and evolution of the Gulf of Corinth rift, Greece, Geophysical Journal International, 185, 1189-1219.

Tataris, A., Maragoudakis, N. and Kounis, G., 1970. Geological map of Greece, 1:50000 scale, 'Nemea Sheet', IGSR, Athens.

Zambetakis-Lekkas, A., Pomoni-Papaioannou, F. and Carotsieris, Z., 1988. A Middle Cenomanian - Lower Turonian (?) emergence episode in the Tripolitza subzone (Central Peloponnesus, Greece), Rev. de Paléobiologie, 7, 1, 129-136.

Zambetakis-Lekkas, A., Vartis-Matarangas, M. and Alexopoulos, A., 1995. La sédimentation sur la plateforme de Tripolitza au Crétacé inférieur - Cénomanien en Crète centrale (Grèce), Cretaceous Research, 16, 311-325.

Zambetakis-Lekkas, A., Pomoni-Papaioannou, F. and Alexopoulos, A., 1998. Biostratigraphical and sedimentological study of Upper Senonian - Lower Eocene sédiments of Tripolitza platform in Central Crete (Greece), Cretaceous Research, 19, 715-732.

Zambetakis-Lekkas, A., Pomoni-Papaioannou, F. and Alexopoulos, A., 2007. New stratigraphic and palaeogeographic data from the Mesozoic strata of the Tripolitza platform in central Crete. Evidence of subaerial exposures during Albian-Early Cenomanian, Hellenic Journal of Geosciences, 42, 7-18. 